NBER WORKING PAPER SERIES

\title{
GLOBAL IMBALANCES AND THE LESSONS OF BRETTON WOODS
}

\author{
Barry Eichengreen \\ Working Paper 10497 \\ http://www.nber.org/papers/w10497 \\ NATIONAL BUREAU OF ECONOMIC RESEARCH \\ 1050 Massachusetts Avenue \\ Cambridge, MA 02138 \\ May 2004
}

The views expressed herein are those of the author(s) and not necessarily those of the National Bureau of Economic Research.

(C)2004 by Barry Eichengreen. All rights reserved. Short sections of text, not to exceed two paragraphs, may be quoted without explicit permission provided that full credit, including (C) notice, is given to the source. 
Global Imbalances and the Lessons of Bretton Woods

Barry Eichengreen

NBER Working Paper No. 10497

May 2004

JEL No. F0, F3, N0

\section{$\underline{\text { ABSTRACT }}$}

An influential school of thought views the current international monetary and financial system as Bretton Woods reborn. Today, like 40 years ago, the international system is composed of a core, which has the exorbitant privilege of issuing the currency used as international reserves, and a periphery, which is committed to export-led growth based on the maintenance of an undervalued exchange rate. In the 1960s, the core was the United States and the periphery was Europe and Japan. Now, with the spread of globalization, there is a new periphery, Asia, but the same old core, the United States, with the same tendency to live beyond its means.

This view suggests that the current pattern of international settlements can be maintained indefinitely. The United States can continue running current account deficits because the emerging markets of Asia and Latin America are happy to accumulate dollars. There is no reason why the dollar must fall, since there is no need for balance of payments adjustment; in particular, the Asian countries will resist the appreciation of their currencies against the greenback.

I argue that this image of a new Bretton Woods System confuses the incentives that confronted individual countries under Bretton Woods with the incentives that confronted groups of countries. It imagines the existence of a cohesive bloc of countries called the periphery ready and able to act in their collective interest. I argue, to the contrary, that the countries of Asia constituting the new periphery are unlikely to be able to subordinate their individual interest to the collective interest. This image of the current system as Bretton Woods reborn also overlooks how the world has changed since the 1960s. This alternative reading of history and current circumstances suggests that even if there exists today something vaguely resembling the Bretton Woods System, it is not long for this world.

Barry Eichengreen

University of California, Berkeley

Department of Economics

549 Evans Hall, \#3880

Berkeley, CA 94720-3880

and NBER

eichengr@econ.berkeley.edu 


\section{Global Imbalances and the Lessons of Bretton Woods \\ Barry Eichengreen \\ University of California, Berkeley \\ May 2004}

\section{Introduction}

An influential school of thought views the current international monetary and financial system as Bretton Woods reborn. ${ }^{1}$ Today, like 40 years ago, the international system is composed of a core and a periphery. The core has the exorbitant privilege of issuing the currency used as international reserves and a tendency to live beyond its means. The periphery, which still has a way to go in catching up to the core, is committed to export-led growth based on the maintenance of an undervalued exchange rate, a corollary of which is its massive accumulation of low-yielding international reserves issued by and denominated in the currency of the center country. In the 1960s, the core was the United States and the periphery was Europe and Japan, many developing countries not yet having been fully integrated into the international system. Now, with the spread of globalization, there is a new periphery, the emerging markets of Asia and Latin America, but the same old core, the United States, with the same tendency to live beyond its means. The main difference between now and then, aside from the names of the players, is the existence of a third bloc, Europe, which has neither the periphery's scope for catch-up nor the reserve-currency country's ability to live beyond its means, which is why it feels under pressure.

This view yields strong predictions. It suggests that the current pattern of international settlements can be maintained indefinitely. The United States can continue running current account deficits because the emerging markets of Asia and Latin America

\footnotetext{
${ }^{1}$ See Dooley, Folkerts-Landau and Garber (2003).
} 
are happy to accumulate dollars. There is no reason why the dollar must fall further, since there is no need for balance of payments adjustment; in particular, the Asian countries will resist the appreciation of their currencies against the greenback. That China has as a rural population of 200 million underemployed workers yet to be absorbed into the modern sector, something that it can do at the rate of only 10 million to 20 million a year, suggests that it will remain committed to its strategy of export-led growth for a decade and perhaps even two. The current pattern of exchange rates and international payments can be preserved for at least as long.

This way of viewing the pattern of international settlements and the structure of the international monetary and financial system has much to recommend it. For one thing, it encourages us to consider how national balances of payments fit together as interdependent elements of a larger system. Systemic analyses were once commonplace in the literature on the international monetary and financial system; in recent decades they have fallen out of fashion. Proponents of the new view should be commended for reminding us that there is such a thing as the international monetary system and of the fact that the global balance of payments (inclusive of reserve changes) must sum to zero, something that should have implications for how we think about the world.

In addition, this new view helps us to understand how the current pattern of global imbalances arose in the first place. Asian countries have long been committed to policies of export-led growth. Pegged exchange rates and resistance to pressures for revaluation as their economies and current accounts strengthen have been at the center of their development strategies. In pursuing this approach China is following in the footsteps of the newly industrializing economies of East Asia which are themselves following in the 
footsteps of Japan. There is no question that their accumulation of reserves is a concomitant of intervention in the foreign exchange market to keep their currencies down, which is in turn a concomitant of the strategy of promoting exports as a way of stimulating growth. If this means lower incomes and living standards for the time being, relative to those that could be achieved in the short run if currencies were allowed to appreciate, then this is perfectly fine so long as it translates into faster growth and even higher living standards down the road.

The analogy with Europe in the 1950s and 1960s is direct. I myself have characterized the European social compact in this period as a willingness to trade wage restraint and accept lower levels of consumption in return for faster investment and export growth rates that promised to deliver significantly higher living standards down the road. ${ }^{2}$ Other authors (e.g. Ohkawa and Rosovsky 1973) have emphasized the role of the same factors in the high-growth period in Japan. Exchange rates that were increasingly undervalued as the period progressed were integral to this process. ${ }^{3}$

There is no question that the United States plays a unique role in the international monetary and financial system today, as it did 40 years ago. It has been able to run persistent current account deficits without seeing the dollar fall significantly against the currencies of the periphery because the latter are concerned to preserve their position in the U.S. market. This prompts countries in the periphery to intervene with purchases of dollars in order to keep their exchange rates from appreciating. Their willingness to

\footnotetext{
${ }^{2}$ In Eichengreen (1996a).

${ }^{3}$ Another way of seeing that the yen and many European currencies became increasingly undervalued as the postwar period progressed was that the current account no longer bound as a constraint during upswings (when imported input requirements had traditional risen even more quickly than export revenues) in the second half of the 1960s. Indeed, one way of calculating European and Japanese real exchange rates in this period is by converting European and Japanese wages into dollars at the prevailing nominal rate and comparing them with U.S. wages. This reminds us that wage restraint and undervalued exchange rates are simply two sides of the same coin.
} 
accumulate reserves is a consequence of expanding economies and expanding trade. It is reinforced by a lesson drawn from the emerging market crises of the 1990s, namely that the world is a risky place and that governments must insure against sudden shifts in financial flows. ${ }^{4}$

In turn, these policies affect the incentive for the United States to adjust its policy mix. It feels less pressure rein in public spending - to choose between guns and butter in the 1960s terminology - because the additional dollar-denominated securities that it is pumping into the world economy are happily absorbed by Asian central banks. The result is less dollar depreciation and less imported inflation. This means less pressure on the Fed to raise interest rates, relieving the central bank of the need to choose between price stability and growth- and employment-friendly monetary policies. The federal government, enjoying low funding costs, can have its cake and eat it too, boosting spending on both defense and social programs without having to resort to tax increases.

So much for praise. In this paper I will argue that this image of a new Bretton Woods System is a misleading way of thinking about the prospects for the international monetary and financial system in the $21^{\text {st }}$ century. It confuses the incentives that confronted individual countries under Bretton Woods with the incentives that confronted groups of countries. It imagines the existence of a cohesive bloc of countries called the periphery ready and able to act in their collective interest. The idea that such a cartel existed in the 1960s is not entirely farfetched; it was called the Gold Pool. ${ }^{5}$ But history shows that this cartel, like most cartels, proved impossible to hold together when the need

\footnotetext{
${ }^{4}$ Insurance that can be obtained by augmenting their reserves.

${ }^{5}$ The Gold Pool, made up of Belgium, France, Germany, Italy, the Netherlands, Switzerland, the United Kingdom and the United States, is discussed at further length below. It was a formalization of an ad hoc agreement between the U.S. and other countries to intervene to stabilize prices in the London gold market following the "excitement" created by the 1960 presidential election.
} 
was greatest - that is, when collective action was needed for the maintenance of the system. I will argue that the same point applies today: that the countries of Asia constituting the new periphery are similarly unlikely to be able to subordinate their individual interest to the collective interest.

The other way that this picture of a new Bretton Woods System misleads is that it underestimates how dramatically the world has changed. First, the members of the periphery are more numerous and heterogeneous today than in the 1960s. Back then we were talking about Europe and Japan. The countries of Europe had a shared historical experience and had already moved down the road toward building institutions to facilitate collective action and transnational governance. In today's Asia, in contrast, stages of economic development and hence policy priorities are less homogeneous. This makes defining the collective interest more difficult. Moreover, regional cooperation is more weakly institutionalized than in Europe even 40 years ago. All this renders dubious the assumption that Asian countries will collectively work to maintain the status quo.

Second, shifting out of dollars is only as attractive as the next best alternative. By the mid-1960s U.S. monetary gold reserves had fallen to barely half the $\$ 25$ billion reached in the second half of the 1940s. Globally, gold was in inelastic supply. Sterling, the second most important reserve currency, was hardly an attractive alternative. Whether or not central banks liked this situation, it lent stability to the prevailing international system. Now, in contrast, there is the euro.

Third, the readiness of foreign central banks to hold onto dollars and the cohesiveness of their cartel depend on their perception of the reserve-currency country's commitment to maintaining the value of their claims. Under Bretton Woods there was at 
least a putative commitment to maintain the dollar's convertibility into gold at a fixed price. Now, in contrast, the intentions of U.S. policy makers are more obscure. The prospects for the dollar maintaining its value against foreign currencies are also more dubious than they were in the 1960s to the extent that U.S. external deficits today reflect the country's low savings rate, which does not bode well for the future sustainability of its debt at current price levels. In contrast, U.S. capital outflows in the 1960s reflected high savings rates, which should have had more favorable implications for debt sustainability.

Fourth, the removal of capital controls makes it harder to bottle up private financial transactions which apply pressure to the current constellation of exchange rates. This forces central banks today to undertake more extensive, more costly, and more difficult sterilization and intervention operations in order to maintain the status quo.

Fifth, the liberalization of domestic financial markets means that keeping the exchange rate low and domestic savings high no longer guarantees that additional investment will be centered in the traded goods sector. In the present deregulated financial environment there is a tendency for loose credit conditions to pump up investment in nontradables, notably property, fueling building booms and heightening financial fragility. Asian governments are increasingly aware that the current strategy entails these risks, creating an incentive to modify it sooner rather than later.

The final point is that Asian policy makers are not ignorant of this history. They understand that the world has changed in ways that diminish the attractions of systematic undervaluation designed to promote export led growth. This makes it less likely that they will blindly repeat the policies of the past. 
This alternative reading of history and current circumstances has very different implications for the process of global adjustment. It suggests that even if there exists today something vaguely resembling the Bretton Woods System, it is not long for this world.

In the remainder of this paper I elaborate this argument in three ways. First I review the history of Bretton Woods in order to highlight the collective action problem facing countries seeking to support the operation of this kind of international system. Next I describe in more detail how current circumstances differ from those of 40 years ago. Finally I suggest an alternative scenario for how events could unfold from here.

\section{Back to the Future}

Bretton Woods was a compromise between competing visions of the post-World War II monetary order. For present purposes it is sufficient to adopt the conventional distinction between the British view and the U.S. view, or between the Keynes Plan and the White Plan, although in reality there were a number of additional visions represented at the 1944 meeting convened in Bretton Woods, New Hampshire. The U.S. attached

priority to stable money, understandably given the monetary turmoil that the country had endured in the 1930 s, while the British attached priority to monetary room for maneuver, again understandably given how the Bank of England had been inhibited from adapting policy to the needs of the economy in the 1920s. The compromise was one in which gold was made the ultimate anchor of the Bretton Woods System but subject to qualifications that enhanced the autonomy of central banks. The United States accepted, indeed embraced, the obligation of paying out gold at $\$ 35$ an ounce. But this obligation was 
extended only to its official foreign creditors, not to private market participations. ${ }^{6}$ And other currencies could be pegged to the dollar rather than gold.

This first compromise was related to a second, namely between the U.S. desire for pegged exchange rates to promote the recovery of international trade, and the British desire for exchange rate adjustments to accommodate the policies necessary for the maintenance of internal balance. Here the result was the awkwardly-named "adjustable peg," which was more adjustable in theory than in practice. Exchange rates could be changed, at least in principle, under carefully unspecified conditions. ${ }^{7}$ This was what allowed Keynes in his famous speech to the House of Lords to insist that the United Kingdom was not in fact tying itself to a new gold standard.

And, in turn, that second compromise was related to a third, namely between the U.S. desire for currency convertibility and British insistence on the maintenance of controls. The result was a commitment to the early restoration of current account convertibility, which occurred in Europe at the end of 1959 and in Japan several years later, but combined with authorization to maintain controls on capital account transactions for an indefinite period, which for some countries has meant up to the present day. ${ }^{8}$

The parallels with our current international monetary system will be evident. While the Bretton Woods System was nominally gold based, from the start it was really a gold-dollar system, and from 1968 with the creation of the two-tier gold market, and especially from the summer of 1971 with the closure of the gold window, it was

\footnotetext{
${ }^{6}$ The U.S. having demonetized gold in 1934.

${ }^{7}$ Namely, if the currency was in a position of fundamental disequilibrium. By "carefully unspecified conditions" I refer to the fact that a conscious decision was taken not to define the meaning of this term. ${ }^{8}$ It took a couple of additional years for Article VIII convertibility to be recognized by the International Monetary Fund.
} 
effectively a dollar standard. Given the inelasticity of global gold supplies, dollars provided essentially the entire increase over time in international reserves, other currencies playing a negligible role. Agreement to create Special Drawing Rights in 1968, which took several additional years to operationalize, came too late to change this fundamental fact. ${ }^{9}$

While countries other than the United States could only acquire additional reserves if the U.S. ran balance of payments deficits, those deficits created discomfort for a number of reasons. ${ }^{10}$ Its status as the reserve-currency country evidently allowed the United States to live beyond its means: the U.S. could import foreign merchandise, acquire foreign companies, and engage in foreign military adventures all at the same time. Charles De Gaulle and many of his countrymen found these last two privileges particularly objectionable. Pressure on the dollar price of gold and official gold losses were a chronic preoccupation of U.S. policy makers in the 1960s, but their existence did nothing to assuage complaints that the U.S. had an "exorbitant privilege" by virtue of the dollar's exceptional position under Bretton Woods.

Another reason why large stocks of dollar reserves were uncomfortable for foreign central banks and governments was growing uncertainty about whether dollars would maintain their value. If the dollar was devalued against gold or other currencies, foreign central banks would incur capital losses. If they sought to protect themselves by swapping dollars for gold, they might precipitate the very crisis of which they were increasingly concerned. If the United States attempted to defend the dollar by adopting more restrictive monetary and fiscal policies or, more likely given domestic political

\footnotetext{
${ }^{9}$ The first allocation of SDRs was only issued in 1970-72.

${ }^{10}$ This aspect of the process created discomfort for academics as well, notably for Robert Triffin, my Yale professor of international economics, who had warned of the problem in Triffin (1960) and even before.
} 
imperatives, resorting to protectionism to curtail the demand for imported merchandise, foreign economies would lose access to the major export market on which they were so dependent. These same considerations rendered foreign governments reluctant to revalue against the dollar, despite their relatively rapid growth, rising competitiveness, accretion of reserves, and reservations about U.S. balance of payments deficits. ${ }^{11}$

All this has a remarkably contemporary ring. Then as now, other countries welcomed their ability to acquire dollar reserves, and they valued their access to a buoyant U.S. export market. They were reluctant to revalue for fear of how this would affect both the prospects for export-led growth and the stability of the international monetary and financial system. Discerning no alternative, they resorted to a variety of ad hoc measures to keep the system running for more than a decade. One possible implication is that contemporary policy makers see no alternative to doing the same.

At the same time, the 1960s differed in important ways. For one thing, in contrast to the current position, the U.S. trade balance and current account were in substantial surplus all through the period. The U.S. trade balance had been in surplus continuously since World War II. The U.S. current account was similarly in surplus every year from 1954 to 1971 (when the combination of leads and lags and J-curve effects did it in), with the single exception of 1959. The U.S. current account continued to strengthen through the first half of the 1960s until mounting U.S. military expenditure abroad led to the progressive diminution of the surplus balance. ${ }^{12}$ But a surplus there was.

\footnotetext{
${ }^{11}$ The only noteworthy revaluations of the period were those of Germany and the Netherlands in 1961 and Germany in 1969.

${ }^{12}$ U.S. direct military expenditures abroad rose sharply after 1965 . The deterioration of the balance on government account was almost a mirror image.
} 
Throughout this period, then, the United States was a net investor in the rest of the world. Contemporaries were conscious of the fact; these were the very years when critics in France and elsewhere became aware of the growing presence of U.S.-based multinational corporations and worried that the United States was buying up their assets on the cheap.

To some extent this foreign investment was a natural consequence of America's status as banker to the world, a mantle she had taken over from Britain. As the country with the deepest, most liquid and most sophisticated financial markets, the U.S. provided financial intermediation services to the rest of the world by importing short-term capital and exporting long-term capital. Foreigners were attracted to the liquidity provided by U.S. treasury bills and bank deposits, but they also needed the long-term investments of U.S.-based multinational corporations. ${ }^{13}$ With a comparative advantage in financial intermediation, the country had a natural tendency to provide maturity transformation services, as emphasized by authors like Charles Kindleberger. ${ }^{14}$ There was an unfortunate tendency to confuse what was a competitive strength in the provision of financial-intermediation services with problems of inadequate international competitiveness. That tendency was aggravated by the publication of balance of payments accounts using concepts like the basic balance, which excluded short-term capital flows from the balance-of-payments accounts while including long-term flows. ${ }^{15}$

But that the United States, the country with the deepest and most liquid financial markets, possessed a comparative advantage in exporting financial services was no

\footnotetext{
${ }^{13}$ Solomon (1982) rightly refers to French views of U.S. foreign direct investment as "schizophrenic." Even while opinion leaders worried about U.S. dominance of the French economy, practical policy makers recognized the fundamental need for long-term U.S. investment.

${ }^{14}$ See Kindleberger (1965).

${ }^{15}$ On the grounds that short-term flows were more volatile and subject to unpredictable reversals.
} 
guarantee that this would remain the case. While the U.S. had a head start in the development of financial markets, given the draconian controls imposed by other countries in the wake of World War II, increasingly well-developed bank intermediation provided an alternative to securitized finance. Moreover, financial liberalization and financial development were ongoing. Catch-up in finance was simply one aspect of the broader catch-up process in the OECD over the quarter century following World War II.

And, as Peter Garber has noted elsewhere, if accelerating inflation raised the danger of capital losses on U.S. investments, other countries would find it less attractive to obtain these maturity-transformation services by investing in liquid bank deposits and treasury securities in the United States and receiving less liquid foreign direct investment in return. ${ }^{16}$ At some point, the terms of trade would be sufficiently unattractive that short-term capital inflows might stop and even reverse direction. If long-term flows were slower to reverse, as contemporaries assumed, the result could be a crisis for the United States whether or not the country had been serving as banker to the world.

Still, from the present perspective, the composition of capital flows is a subsidiary concern. The key point is that the net direction of flows was strongly outward. Domestic savings exceeded domestic investment all through the 1960s (albeit by a small margin in 1968 and 1969). The excess savings could be invested abroad in earning assets - the foreign branch plants of U.S.-based corporations, foreign government securities, and a variety of other foreign assets - the interest and dividends on which would represent a credit item on the balance of payments down the road. In the event, these expectations of future credits did not suffice to reassure the markets. But imagine how much worse things would have been - how much more quickly confidence in the system would have

\footnotetext{
${ }^{16}$ Garber (1993), pp.470-474. This is of course the same author referred to in footnote 2 above.
} 
ebbed - had there exited in addition other distortions depressing U.S. savings rates and resulting in current account deficits.

In retrospect, it is striking for how many years jerry-rigged solutions kept the system afloat. Determining whether this should be regarded as promising for future efforts to keep the current "non-system" afloat requires examining the motives and tactics of officials in more detail. Although the reallocation of monetary gold from U.S. coffers to those of the rest of the world was a fundamentally healthy phenomenon - circa 1947 the U.S. had possessed an unsustainably large 70 per cent of the world total - by the end of the 1950 s the U.S. share had fallen to less than 50 per cent and the trend was viewed with alarm. There had been a particularly large drop in U.S. gold reserves in 1958 in the aftermath of the Suez crisis. ${ }^{17}$ The shift of the current account from surplus to deficit in 1959 created worries of more deficits to come. For much of 1960, the international monetary intentions of the Democratic presidential candidate, John F. Kennedy, were obscure; his emphasis on "getting the economy going again" did not reassure dollar bears. Although Kennedy asserted even before the election that he had no intention of devaluing the dollar, there was still a tendency on the part of market participants to reason by analogy with 1933, the last time that a Democrat had taken over from a Republican as president, and when one of the new president's first actions had been to raise the dollar price of gold. ${ }^{18}$ Thus, prices in the London gold market shot up in

\footnotetext{
${ }^{17}$ This is the emphasis of Block (1977). In 1956 the United States had insisted that France, the UK and Israel withdraw from Suez, and Washington threatened to use its political leverage for force their compliance if necessary. This episode there led to political problems and economic difficulties, most notably in France in 1957-8. In turn this may have hardened French opposition to a dollar-based international monetary system.

18 "First, we pledge ourselves to maintain the current value of the dollar. If elected President I shall not devalue the dollar from the present rate. Rather I shall defend the present value and its soundness," spoke candidate Kennedy in Philadelphia on 31 October 1960 (Roosa 1967, p.268). Now there is a strong dollar policy if I have ever heard one.
} 
October 1959 to $\$ 40$ shortly before the U.S. election. Only concerted intervention by

European central banks, led by the Bank of England, brought them back down.

Any divergence between the official U.S. and London market prices of gold created a temptation for central banks to buy gold from the United States for $\$ 35$ and sell it on the London market at a higher price. Their ability to do so was limited only by their liquid dollar reserves. From a collective standpoint doing so might be undesirable insofar as it depleted U.S. gold reserves and cast doubt over the country's commitment to convert gold into dollar as a fixed price. But for the individual central bank there was an incentive to engage in such conversions before the gold window slammed shut, as ultimately happened in 1971, leaving those who had exercised restraint without options. This created an obvious problem of collective action. ${ }^{19}$

This is the context in which the Gold Pool was created in 1961. The Gold Pool was an arrangement whereby central banks sought to share the cost of maintaining the London price of gold at $\$ 35$ an ounce rather than depleting U.S. gold reserves. ${ }^{20}$ It encouraged collective action by establishing an understanding of how the costs of these operations would be divided - that is, of what share of the gold that needed to be sold in London in order to stabilize the market price would be provided by each participating central bank.

\footnotetext{
${ }^{19}$ Private investors, in contrast, could not undertake these arbitrage operations directly, but many of them had the right to buy gold on the London market, in anticipation of the fact that its price would rise if U.S. gold reserves were exhausted. In addition, foreigners could "put" their dollar holdings to their own central banks by exchanging dollars for the local currency to avoid the losses that would follow if the dollar was devalued. By enlarging the dollar positions of European central banks, this raised the stakes for countries seeking to exercise individual self restraint in the collective interest. As Garber (1993) notes, it is surprising that contemporaries focused on liquid foreign dollar holdings to the exclusion of liquid dollar holdings in the United States. In principle, there would seem to have been myriad ways in which U.S. residents could have used their domestic balances to buy gold or foreign currencies in London. Whether their failure to do so on a larger scale reflects the operation of the Interest Equalization Tax, the Buy American Program or some other device is unclear. I return to this below.

${ }^{20}$ The actual intervention price was $\$ 35.20$, the official $\$ 35$ U.S. price plus the costs of shipping and insurance of getting gold to London.
} 
But foreign central banks were not prepared to continue sharing these costs indefinitely. Even in its heyday, central banks other than the Fed provided barely more than a third of the gold reserves sold into the pool. ${ }^{21}$ In principle, the Gold Pool shifted only some of the pressure of maintaining the $\$ 35$ gold price in London away from the United States. And, in practice, other central banks were still free to offset their sales into the pool with purchases from the U.S. authorities. As a group, members of the pool other than the U.S. actually added to their gold reserves in this period, while the U.S. was forced to make additional gold sales outside the pool in roughly matching amounts. This may have been inconsistent with the spirit of the cartel agreement, but there was nothing that the U.S. could do about it. France was the most blatant case: it bought $\$ 884$ million of gold from the United States in 1965, despite running an overall balance of payments surplus of only $\$ 619$ million (as measured by the total increase in its reserves). In 1966 it bought $\$ 601$ million of gold from the U.S. despite a total increase in reserves of only $\$ 390$ million. $^{22}$ And the more gold that France acquired from the United States, the greater was the temptation for other central banks to do the same. ${ }^{23}$

In part the incentive problem arose from the fact that there did not exist a limit on the obligations of other central banks: there was no adjustment mechanism that guaranteed to return prices in the London market to the official price of $\$ 35$ an ounce and

\footnotetext{
${ }^{21}$ It is revealing that the U.S. share was especially high as the arrangement drew to an end and other central banks, notably the Bank of France, grew increasingly reluctant to participate in the system. Solomon (1982) notes how the U.S. had to airlift gold to London using Air Force planes in order to keep the Gold Pool afloat at the end of 1967.

${ }^{22}$ In the summer of 1967 it discontinued sales into the pool, a fact that became known later in the year (see below).

${ }^{23}$ According to Meltzer (1991), the Gold Pool never worked as an effective cartel, these replacement purchases of gold by European central banks functioning in the same manner as surreptitious oil sales by members of the OPEC cartel.
} 
thereby allow the Gold Pool to be disbanded. ${ }^{24}$ France demanded a more contractionary

U.S. monetary policy as a quid pro quo for its continued participation. When this was not forthcoming, it withdrew, and the pool collapsed.

There followed a "Gentlemen's Agreement" in which central banks promised not to convert their inherited dollar balances but remained free to convert any additional dollars they accumulated starting in 1968. But since there was no other way by which their need for additional reserves could be satisfied, the writing was on the wall. In the short run, the U.S. could replenish its reserves by attracting capital and purchasing gold from France, where the events of May 1968 created uncertainty about future policy. But this was only a temporary respite. The holes in the Gentlemen's Agreement became gaping in 1970, when Belgium and the Netherlands exchanged dollars for gold, Germany signalled its desire to do likewise, and France indicated that it would demand gold for dollars in order to make a repayment to the IMF. The last straw came on 13 August, when Britain requested gold. The gold window was then shut in short order.

It is worth asking whether things might have turned out differently. Would more monetary and fiscal restraint in the United States have allowed this system to continue on for a longer period? Could the United States have devalued the dollar against gold and

\footnotetext{
${ }^{24}$ Robert Solomon, then working for the Federal Reserve Board, recognized this problem, and proposed linking the continuation of the gold pool with the creation of a new reserve asset (along the lines of what eventually became the SDR). See Solomon (1982), pp.115-116. As it happened, the collapse of the Gold Pool and the creation of a two-tier gold market in 1968 with one price (the London market price) for private transactions and a second price ( $\$ 35$ an ounce) for officials transactions did help to restore equilibrium after a fashion. The rise in the market price created an incentive for South Africa to expand its gold production and sales, eventually driving the market price back down to $\$ 35$. But this response occurred only after the official and market prices of gold were decoupled, and it took a considerable period of time to operate. This was precisely how the maintenance of price stability was supposed to work under the classical gold standard. (For a modern statement of the mechanism, see Barro 1979.) Under the classical gold standard as well, the problem was that the induced response of the gold mining industry took a considerable period of time to operate (Eichengreen 1996b). In the meantime, the signals sent by the divergence of the two prices reminded central banks of the incentives to hedge their bets.
} 
foreign currencies as a way of stemming the secular decline in its current account surplus in the second half of the 1960s?

The answer to the second question has two aspects. First, if the U.S. chose to raise the price of gold once, it would have almost certainly excited expectations that it was prepared to do so again. ${ }^{25}$ An early run on U.S. gold reserves would have become correspondingly more likely. A way around this would have been to allow the dollar price of gold to float, as proposed by Meltzer (1966), but this would have represented breaking the gold-dollar link once and for all - something that the U.S. was unwilling to contemplate until it found itself with no choice in 1973.

Second, there is the question of whether the U.S. in fact had the capacity to devalue against the currencies of countries which pegged to the dollar rather than gold. Foreign central banks could simply follow dollar for dollar, as it were, if the U.S. raised the dollar price of gold. There are indications that at least some of them were prepared to do so. ${ }^{26}$ More than a few countries in fact did so in 1971, when the U.S. finally raised the gold price. This is not unlike the current situation, in which Asian central banks have been prepared to follow the U.S., in their case preventing their currencies from appreciating by buying dollars and accumulating reserves.

On the other hand, would more monetary and fiscal restraint by the United States have permitted this system to stagger on for a significant additional period? In principle, the government could have raised taxes, and the Fed could have raised interest rates. By

\footnotetext{
${ }^{25}$ Opting to raise the dollar price of gold would have also politicized subsequent decisions, since the Administration would have had to go to the Congress for approval to raise the $\$ 35$-an-ounce price.

${ }^{26}$ See Shultz and Dam (1977) and Gowa (1983). Nixon's import surcharge, however, regrettable on other grounds, provided the U.S. with a bargaining chip that could be used to discourage other countries from following the U.S. dollar for dollar. The problem with the unilateralism of the import surcharge was that it greatly complicated efforts to cooperate in good faith on redesign of the international monetary system.
} 
curtailing domestic demand and enhancing U.S. export competitiveness, this would have further strengthened the current account. It is not clear how other countries would have responded. On the one hand, the slower growth of U.S. markets for their exports would have slowed the expansion of their own economies, limiting the incentive for them to respond with parallel policy adjustments. Less inflation in the United States would have enhanced the attractions of tapping the New York market for maturity-transformation services, stimulating capital inflows. For all of these reasons, U.S. gold reserves presumably would have declined less rapidly in this counterfactual. The revaluation of the deutschemark in 1969, which did so much to signal the impending demise of the dollar standard, would presumably have been delayed.

But it would not have been delayed indefinitely. As the world economy continued to grow, other countries would have continued to require additional reserves, and there were few forms in which to obtain them other than liquid claims on the U.S. government or U.S. gold reserves. Seeing their current accounts weaken and short-term capital outflows to the U.S. accelerate in response to the American policy initiative, foreign central banks and governments would have had an incentive to tighten in order to offset these effects. The main way in which the day of reckoning would have been delayed under this counterfactual was by slowing the rate of growth of the world economy and thereby the growth in demand for international reserves. In other words, while the Triffin Dilemma would not have disappeared under this counterfactual, its consequences would have taken longer to play themselves out. ${ }^{27}$

\footnotetext{
${ }^{27}$ The simulation model developed and analyzed in Bordo and Eichengreen (1998) points to precisely this conclusion.
} 
In practice, central banks would probably have staked out a middle ground between the extremes of doing nothing in order to sustain domestic growth and tightening in order to augment their reserves. ${ }^{28}$ When push came to shove, the imperatives of domestic growth dominated the desire to defend the dollar and sustain the operation of the international monetary system. This was nowhere more true than in the United States itself, where policy makers went to great lengths to avoid having to adopt restrictive macroeconomic initiatives in support of the exchange rate, insofar as these might slow the rate of growth of the economy and hinder the pursuit of social- and foreign-policy objectives. ${ }^{29}$ This explains the extraordinary variety of ad hoc devices to which they resorted to strengthen the U.S. balance of payments without having to change monetary and fiscal policies, from soliciting European support for U.S. military commitments abroad, to tying foreign aid, to tightening limits on the value of duty-free goods that American tourists could bring into the country, to Operation Twist, to the Interest Equalization Tax. ${ }^{30}$

In sum, from the U.S. point of view the Bretton Woods System was all too similar to a gold standard of the late $19^{\text {th }}$ century variety. Given the obligation to convert dollars into gold at $\$ 35$ an ounce and use of the dollar as international reserves by the other participants in the system, the only way that the U.S. could maintain the gold convertibility of the dollar was through internal deflation, which raised the real value of both monetary gold stocks and official foreign dollar balances and encouraged the

\footnotetext{
${ }^{28}$ This implies that the day of reckoning would have been delayed even less than suggested by the second of these two counterfactuals.

${ }^{29}$ On those rare occasions when the Fed did tighten and the executive and legislative branches did agree on a tax hike, as in 1968, the balance of payments recovered, but economic growth suffered. And the counterreaction was intense.

${ }^{30}$ Operation Twist involved attempting to twist the yield curve by selling short-term treasury bills while buying long-term bonds, and thus to stimulate domestic investment with lower long-term rates while attracting capital inflows with higher short-term yields. See Meltzer (1991) and Eichengreen (2002).
} 
production of additional gold in South Africa and elsewhere. In this respect the dilemma was not unlike that facing gold standard countries in the 1870s and 1880s. But political constraints on the pursuit of deflation were stronger than they had been a century before. This was true not only in the U.S., where there was a demand for both social spending at home and military spending abroad, but also in Europe and Japan, where revaluation would have meant more deflation and less export-led growth. Inflation rather than deflation made it less attractive for foreigners to utilize the country's deep and liquid financial markets for maturity transformation services, limiting short-term capital flows toward the United States. Given catch up and productivity growth broad, too much inflation in the U.S. meant too small a current account surplus to finance the country's other obligations. ${ }^{31}$ Dollars thus piled up in the coffers of foreign central banks. This in turn led to desperate efforts to negotiate collective restraints on the individual desire to convert those dollars into an alternative asset that might hold its value better before the bottom fell out of the dollar market. These efforts proved reasonably successful between 1961 and 1968, but when they collapsed it took barely three years for exchange rate stability to break down.

\section{How the World Has Changed}

One way in which the image of a new Bretton Woods System misleads, I have argued, is that it underestimates how dramatically the world has changed since the 1960s. First, the Asian countries that make up the "new periphery" are a less cohesive grouping

\footnotetext{
${ }^{31}$ This phraseology is designed to be consistent with the fact that U.S. wholesale and consumer price inflation was generally lower than inflation in other industrial countries, but insufficiently so for the maintenance of external balance, given rapid catch-up growth (and the operation of the Balassa-Samuelson effect) in these other countries. See Eichengreen (2002).
} 
than the European countries that dominated the periphery in forty years ago. By the 1960s the Europeans had already begun to construct the web of bargains that constitutes the European Union nee European Economic Community. They consulted regularly with one another and with the United States in the OECD. ${ }^{32}$ Indeed, the immediate impetus for transforming the OEEC into the OECD was to provide a mechanism for collective action on the U.S. gold problem. ${ }^{33}$ From October 1963 to June 1964 central bank and finance ministry deputies met monthly in Paris under the aegis of the Group of Ten to discuss the operation of the international monetary system. The outcome of their discussions was agreement to establish a monitoring technology whereby shirking on the commitment to collective action could be detected: a "multilateral surveillance" system obliging all members of the G-10 to provide the BIS with data on the means used to finance their payments surpluses and deficits. ${ }^{34} \mathrm{G}-10$ finance ministers and central governors (and their deputies) continued to meet together thereafter to discuss collective management of the international monetary system. Central bank governors continued to meet at the BIS on a monthly basis. European countries and the United States also worked together in the IMF, where they were the dominant voices (and where they could thus agree, eventually, to responses like the creation of the SDR). Thus, governments and central banks had a variety of mechanisms for addressing their collective action problems - for acting on the recognition that they had a collective interest in supporting the dollar, partly because its depreciation would undermine their export competitiveness

\footnotetext{
${ }^{32}$ For example, in Working Party 3 of the OECD's Economic Policy Committee (see Roosa 1967).

${ }^{33}$ See Roosa (1967). It is revealing that Kennedy had proposed U.S. membership in his balance of payments message (a special message to the Congress on the balance of payments delivered on 6 February 1961 (barely three weeks after the new president took office).

${ }^{34}$ These data were then circulated among the members of the G-10 and to Working Party 3 of the OECD on a confidential basis.
} 
and slow their growth - and they created a monitoring technology that increased the costs of shirking on that agreement. All this may not have been enough to prevent France from defecting from the Gold Pool, but it increased the cost of noncooperative behavior.

In Asia, in contrast, integration is less advanced. Regional free trade initiatives continue to stumble. The ASEAN countries' insistence on exempting sensitive sectors is impressive even compared to European countries' insistence on protecting their agricultural trade. There is no agreement on whether to proceed regionally (China's preference) or through bilateral agreements (Japan's preferred alternative). This is just one illustration of the broader inability of the two big Asian countries to work together, in part reflecting their very different stages of economic development (contrast France and Germany in the 1960s) and therefore their very different policy priorities. ${ }^{35}$

Also symptomatic of the obstacles to regional cooperation is the weakly institutionalized nature of Asian integration. While there exist a variety of groupings (ASEAN, ASEAN+3, EMEAP and APEC, among others), few are backed by formal institutions (not even a permanent secretariat, much less a Parliament, a Commission, and a Court of Justice). ${ }^{36}$ The peer pressure, firm surveillance and political sanctions that encouraged cooperation in Europe in the 1960s still barely exist in Asia. For all these reasons, mechanisms for containing free rider problems are even less well developed there. Collective action may have sustained the Bretton Woods constellation of exchange rates for 13 years from the elimination of current account restrictions at the end of 1958

\footnotetext{
${ }^{35}$ Another example is efforts to promote financial-market development in the region, which have similarly produced more in the way of appearance than substance. Japan is pushing for a regional financial market centered on Tokyo with transactions denominated in yen, while other countries, including China but with the leadership of Thailand, prefer an Asian Bond Fund and Asian Bond Market Initiative structured to encourage the development of an integrated regional financial market in which many centers can flourish and transactions can be denominated in a variety of regional currencies.

${ }^{36}$ Although ASEAN for one has a modest permanent secretariat.
} 
to the closing of the Gold Window in 1971, but these differences in the institutional setting yield a rather more pessimistic forecast of for how many years the current system will endure.

Second, there exist more attractive alternatives to the dominant reserve currency than in the 1960s. Back then the temptation for central banks to diversify out of dollars in order to limit capital losses on their reserve holdings was limited by the fact that the alternatives were hardly more attractive. The second most important reserve currency, the pound sterling, was issued by Europe's “sick man." The events of 1967 made clear that shifting out of dollars into sterling was not a way of avoiding capital losses. The French franc was hardly a more attractive reserve asset, a fact driven home in 1969 when the franc was devalued. Japanese financial markets were not sufficiently open to make it attractive to hold yen-denominated assets. While this was the period when the Euromarkets and Roosa bonds gained prominence, central banks were reluctant to dabble in private securities or to encourage the development of the Euro-markets, which were seen as undermining their monetary control. What alternatives did this leave the Bundesbank's reserve managers? Swiss francs? Switzerland was hardly large enough to solve the problem. And, so long as Germany had no alternative to dollars, the likelihood that all European countries would collectively scramble out of the currency was correspondingly less. ${ }^{37}$

The difference today, obviously, is the euro. The large, liquid market in eurodenominated government securities provides an attractive alternative to the U.S. treasuries for the central banks of the "new periphery." To the extent that the other

\footnotetext{
37 There was always gold, but shifting into gold would have jeopardized the stability of the international system (something that impressed the Germans more than the French).
} 
pressures enumerated here suggest the need for the dollar to decline against foreign currencies, not excluding the euro, that alternative becomes more attractive still.

In addition, Asian central banks and governments are attempting to promote the development of regional bond markets by creating an Asian Bond Fund and pursuing an Asian Bond Market Initiative. The first $\$ 1$ billion of reserves devoted to the Asian Bond Fund is being invested in the dollar-denominated bonds of Asian governments, but Asian Bond Fund II, which is already widely anticipated, is expected to entail the investment of reserves in local-currency bonds. For the time being the Asian Bond Fund initiative is still small potatoes, but it creates scope for reallocating reserve portfolios toward assets denominated in regional currencies - scope that is likely to increase over time. As such it opens up an avenue for reserve reallocation that did not exist in Europe in the 1960s.

Third, there is the fact that trepidation on the part of foreign central banks and governments about the value of their dollar reserves in the 1960s occurred against the backdrop of large - and, through the first half of the decade, growing - current account surpluses. Because the United States. was saving more than it was investing at home, by definition of the current account, it was also investing abroad. Its accumulation of foreign assets, which critics like De Gaulle found so objectionable, implied that the balance of payments would strengthen as the returns on these investments started rolling in. This should have provided at least some reassurance to nervous foreigners. ${ }^{38}$ Now, in contrast, the current account is in deficit. While there is dispute over the causes, majority opinion would assign at least part of the blame to low U.S. savings rates. This means that there is no accumulation of net long-term foreign investments to reassure nervous

\footnotetext{
${ }^{38}$ As authors like Kindleberger sought to argue (see above).
} 
foreigners that, even in the absence of exchange rate changes, the balance of payments will naturally strengthen down the road. ${ }^{39}$

Fourth, the removal of capital controls makes it harder to bottle up the privatesector portfolio adjustments that must be offset by central banks seeking to maintain current exchange rates. Perhaps governments are aware that they have a collective interest in maintaining their dollar reserves, since if they sell them the dollar will only weaken further, undermining their collective competitive position. But whether or not the public sector is able to act on this collective interest, it is clear that collective interest is not something that motivates private investors, each of whom is interested in maximizing his individual return. A large number of individual and institutional investors, both American and foreign, inhabit the U.S. treasury market. In the 1960s the United States could use the Interest Equalization Tax and foreign governments could use regulations and controls to limit the reallocation of private investment portfolios and short-selling of the dollar. In principle U.S. residents still might have found ways "put" their dollar-denominated assets to foreign central banks. ${ }^{40}$ In practice, however, this seems to have happened only to a limited extent. ${ }^{41}$ Now, in contrast, international financial markets and transactions are less regulated and more open. Such transactions are easier to undertake. If private investors are quicker to act in anticipation of future changes in asset prices, the pressure on central banks and governments will be correspondingly greater.

\footnotetext{
${ }^{39}$ Although there is a peculiar tendency for U.S. long-term investments abroad to yield a higher rate of return than foreign long-term investments in the United States.

${ }^{40}$ Which would have thereby increased the pressure on the latter to convert their dollar overhang into gold.

${ }^{41}$ As noted by Garber (1993) and commented on above.
} 
That financial markets are more open today suggests that the same dynamics are likely to operate more quickly and powerfully, frustrating official efforts to put off the day of reckoning. This fact is evident even in China, whose capital account is still far from open (although it is growing more so every day). Massive amounts of private financial capital have been flowing into China in response to the recognition that the current undervaluation of the renminbi will not be sustainable indefinitely. This has forced the Chinese authorities to attempt large-scale sterilization of capital inflows. It is revealing of the difficulties that by the end of last year the commercial banks had grown increasingly reluctant to buy the bills that the central bank issues in its efforts to sterilize the impact of financial inflows on the money supply. ${ }^{42}$

Fifth, the domestic financial market structures in which the consequences of current policies are unfolding are different than 40 years ago. Financial deregulation has limited the scope for funneling forced saving into capital formation in the traded goods sector, which was the strategy of many countries in the 1960s. Keeping exchange rates low in the periphery means keeping interest rates low. Intervening by purchasing dollars means pumping additional domestic credit into the economy, given the limited effectiveness of sterilized intervention. In Japan in the 1960s, much of that additional credit was devoted to capacity building in the traded goods sector because it was channeled that way by the Postal Savings System, which was controlled by the government, and by the commercial banks, whose investment options were tightly regulated. The situation in Europe was not dissimilar. It is thus possible to argue that the first set of distortions - undervalued exchange rates, artificially depressed consumption,

\footnotetext{
${ }^{42}$ See Eichengreen (2004). And, of course, these difficulties will deepen as the state banks are further commercialized and, ultimately, privatized, limiting further the scope for using direct pressure to guide their investment decisions.
} 
and forced savings - was welfare improving because it offset another set of distortions that there would have otherwise been too little investment in a traded goods sector that was the source of positive productivity and growth externalities.

In today's more diversified and deregulated financial environment, in contrast, low interest rates and abundant credit have a greater tendency to spill over into the nontraded goods sector and the property market in particular. Thus in the 1990s, the first time Asian countries pursued policies of export-led growth supported by systematic undervaluation in a significantly deregulated financial environment, a number of them experienced dramatic property-market booms that heightened the fragility of their financial institutions and markets. Recall the tales of cranes and half finished high-rises dotting the Bangkok skyline on the eve of the crisis. Now, less than a decade later, the same policies are again producing frightening real-estate booms, not least in coastal China. Policy makers in the region are not oblivious of these dangers. As they come to see that undervaluation is now doing less to promote exports and more to heighten financial risks, they will have more reason to let their exchange rates rise.

Sixth and finally, governments in the periphery are aware of this history. Bretton Woods reminds them of Herb Stein's adage that something which can't go on forever generally won't. In addition they are aware, precisely because of the historical experience referred to above, that a policy of export-led growth has not just benefits but also costs. They are seeking to build more diversified economies that rely on domestic demand as well as exports. South Korea, which has sought to stimulate the growth of consumer credit, is a prominent, if not entirely reassuring example (since the initiative 
soon led to a crisis in the credit-card industry). China is another case where consumption and not exports are now the most rapidly growing component of aggregate demand.

\section{An Alternative Scenario}

The United States has little incentive to precipitate the consequent adjustment. To the contrary, it is happy living beyond its means. Rather, adjustment will have to be forced by Asia. Eventually there will be a recognition that policies of export-led growth have reached the point of diminishing returns. This recognition will entail the observation that the traditional traded goods sectors are no longer the exclusive locus of productivity- and growth-promoting externalities and that activities like software development, back-office services, and financial intermediation are also sources of positive spillovers. Growth will thus require balanced investment in nontraded and well as traded-goods sectors. Asian countries will have to invest more in higher education. They will have to invest more in housing and urban amenities to make themselves attractive to knowledge workers.

Doing so will require allowing the real exchange rate to rise. The obvious way of allowing the real rate to rise without compromising the commitment to price stability is to curtail intervention in the foreign exchange market. Once one or more Asian countries acknowledge that export-led growth is encountering diminishing returns and curtail their intervention, the cartel of central banks that had been supporting the dollar and preventing Asian currencies from rising will begin to fray. One can imagine a gradual migration out of dollars and into alternative reserve assets like that which occurred after 1968. Given the low yields on yen-denominated assets, the euro is the obvious direction 
for such migration. ${ }^{43}$ In addition, the commitment of Asian governments to encourage the development of a regional bond market may lead them to allocate a growing share of their reserve portfolios toward assets denominated in one another's currencies.

Inertia is still the single strongest determinant of the composition of central bank reserve portfolios. Central banks are buy-and-hold investors; they rarely manage their reserve portfolios actively and have a high tolerance for capital losses. It is thus reasonable to anticipate that Asian central banks will not dump all their dollars at once. But there is good reason to think that the adjustment will accelerate with the passage of time.

This move to greater exchange rate flexibility will be a good thing for Asia. The further decline in the dollar will be a good thing for the adjustment of global payments imbalances. That decline may force the Fed to raise rates more sharply, curtailing domestic absorption. Who knows - the increase in funding costs may even cause some future U.S. administration to do something about the country's fiscal problem. This may not be good news for Europe insofar as public and private portfolio reallocation drives up the value of the euro. While Asian currencies may rise against the dollar, the euro will rise also - and to the extent that currencies are driven in the short run mainly by capital flows, on impact it may rise against the dollar even more.

Much of this is necessarily conjectural. Writing the history of the future is harder than writing the history of the past. My reading of the relevant international monetary

\footnotetext{
${ }^{43}$ Europe faces many problems and challenges, to be sure, including high inherited debt burdens and a looming demographic time bomb. If these simply lead to higher tax rates and slower growth, they will not make the euro any less appealing as a reserve asset, for Europe will still have the deep and liquid bond markets required to make a reserve asset attractive. If on the other hand they lead to secularly declining terms of trade, high inflation as the ECB seeks to inflate away the member state's debt burdens, and/or debt default, the story would be very different. How the debt-cum-demographic crisis will play itself out is of course a different paper.
} 
history is that, while there may be patterns, those patterns do not repeat themselves mechanically. Indeed, there were significant parallels between the Bretton Woods System and classical the gold standard system that preceded it. But those two systems evolved differently, and their final stages played out in different ways. Among other things, the Bretton Woods System was quicker to collapse.

Similarly, there are parallels between the Bretton Woods System of the 1960s and the "revived Bretton Woods System" of our day, as Dooley, Folkerts-Landau and Garber so compellingly argue. But that the original Bretton Woods System lasted between one and two decades, depending on how its birth and death are dated, does not mean that the revived Bretton Woods System will last as long. Both this reading of the history and an appreciation of the extent of changes in the world economy suggest that the end will not be as long in coming this time around. 


\section{References}

Barro, Robert (1979), "Money and the Price Level under the International Gold Standard," Economic Journal 89, pp.13-33.

Block, Fred L. (1977), The Origins of International Economic Disorder: A Study of United States International Monetary Policy from World War II to the Present, Berkeley: University of California Press.

Bordo, Michael and Barry Eichengreen (1998), "Implications of the Great Depression for the Development of the International Monetary System," in Michael Bordo, Claudia Goldin and Eugene White (eds), The Defining Moment: The Great Depression and the American Economy in the Twentieth Century, Chicago: University of Chicago Press, pp.402-453.

Cooper, Richard N. (2000), "Foreign Economic Policy in the 1960s: An Enduring Legacy," in George L. Perry and James Tobin (eds), Economic Events, Ideas, and Policies: The 1960s and After, Washington, D.C.: Brookings Institution, pp.139-184.

Dooley, Michael, David Folkerts-Landau and Peter Garber (2002), "An Essay on the Revived Bretton Woods System,” NBER Working Paper no. 9971 (September).

Eichengreen, Barry (1996a), "Institutions and Economic Growth: Europe After World War II," in Nicholas Crafts and Gianni Toniolo (eds), Economic Growth in Europe Since 1945, Cambridge: Cambridge University Press, pp.38-72.

Eichengreen, Barry (1996b), Globalizing Capital: A History of the International Monetary System, Princeton: Princeton University Press.

Eichengreen, Barry (2002), "From Benign Neglect to Malignant Preoccupation: U.S. Balance of Payments Policy in the 1960s," in George Perry and James Tobin (eds), Economic Events, Ideas, and Policies: The 1960s and After, Washington, D.C.: The Brookings Institution, pp.185-242.

Eichengreen, Barry (2004), "Chinese Currency Controversies," Asian Economic Papers (forthcoming).

Garber, Peter (1993), "The Collapse of the Bretton Woods Fixed Exchange Rate System," in Michael Bordo and Barry Eichengreen (eds), A Retrospective on the Bretton Woods System: Lessons for International Monetary Reform, Chicago: University of Chicago Press, pp.461-494.

Gowa, Joanne S. (1983), Closing the Gold Window, Ithaca: Cornell University Press.

Ohkawa, Kazushi and Henry Rosovsky (1973), Japanese Economic Growth, Stanford: Stanford University Press. 
Kindleberger, Charles P. (1965), "Balance of Payments Deficits and the International Market for Liquidity," Princeton Essays in International Finance no. 46, International Finance Section Department of Economics, Princeton University.

Meltzer, Allan H. (1966), "The Regulation of Bank Payments Abroad, Another Failure for the Government's Balance of Payments Program," in George P. Shultz and Robert Z. Aliber (eds), Guidelines, Informal Controls, and the Market Place, Chicago: University of Chicago Press, pp.183-208.

Meltzer, Allan H. (1991), "U.S. Policy in the Bretton Woods Era," Federal Reserve Bank of St. Louis Review 73 (May/June), pp.54-83.

Roosa, Robert (1967), The Dollar and World Liquidity, New York: Random House.

Shultz, George and Kenneth Dam (1977), Economic Policy Beyond the Headlines, Chicago: University of Chicago Press.

Solomon, Robert (1982), The International Monetary System, 1945-1981, New York: Harper \& Row.

Triffin, Robert (1960), Gold and the Dollar Crisis, New Haven: Yale University Press. 
Figure 1

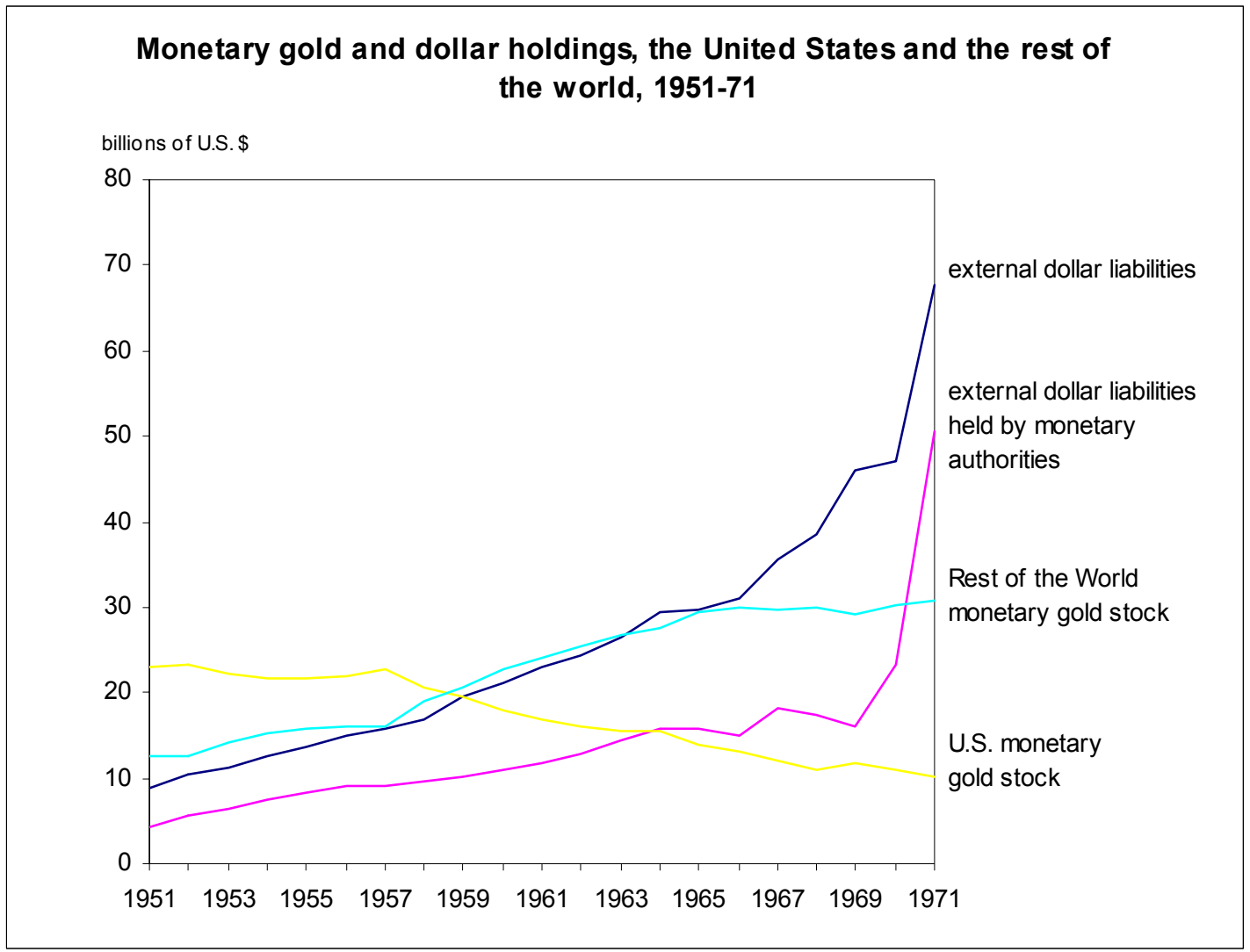

Sources: IMF, International Financial Statistics; U.S. Congress, Report to the Congress of the Commission on the Role of Gold in the Domestic and International Monetary Systems, vol. 1 
Figure 2

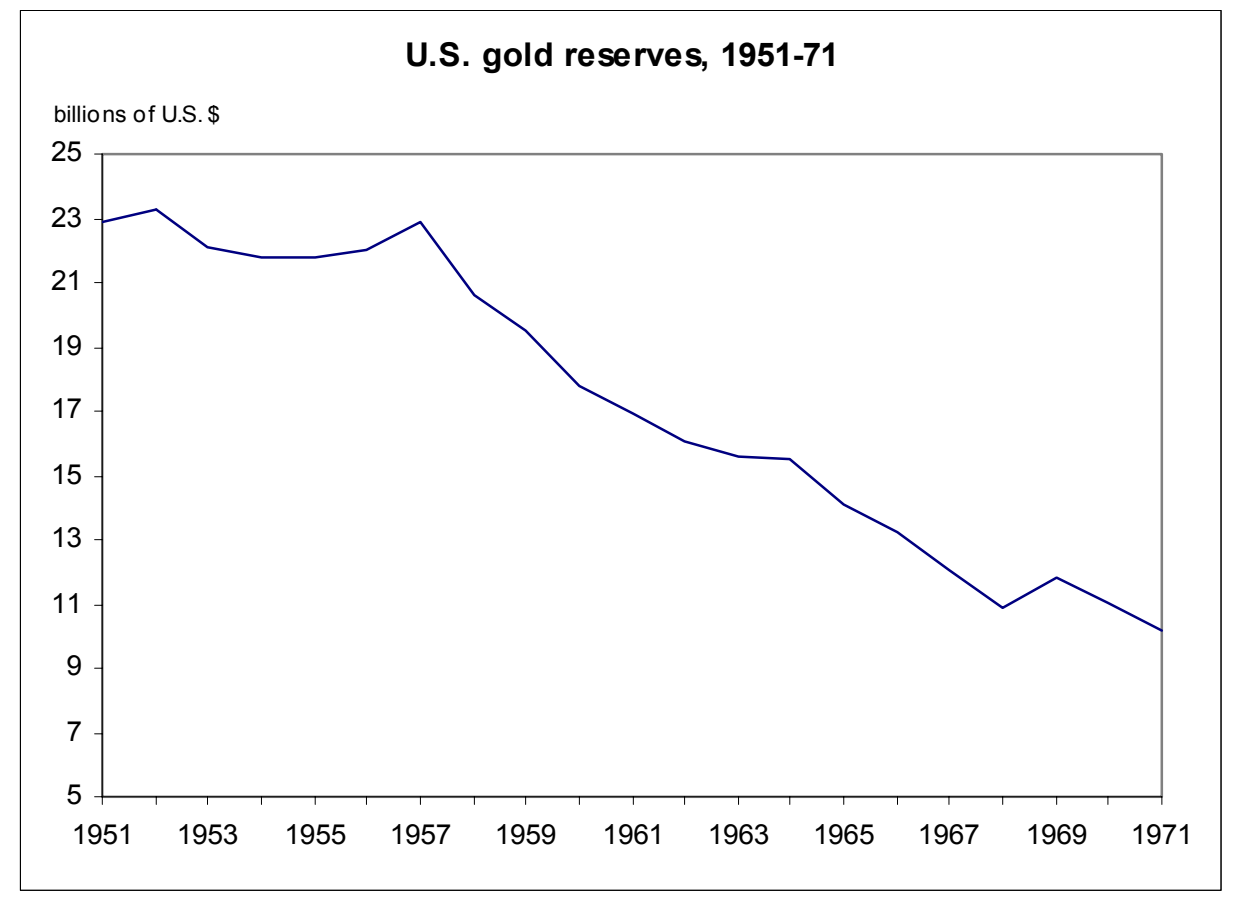

Source: IMF, International Financial Statistics 
Figure 3

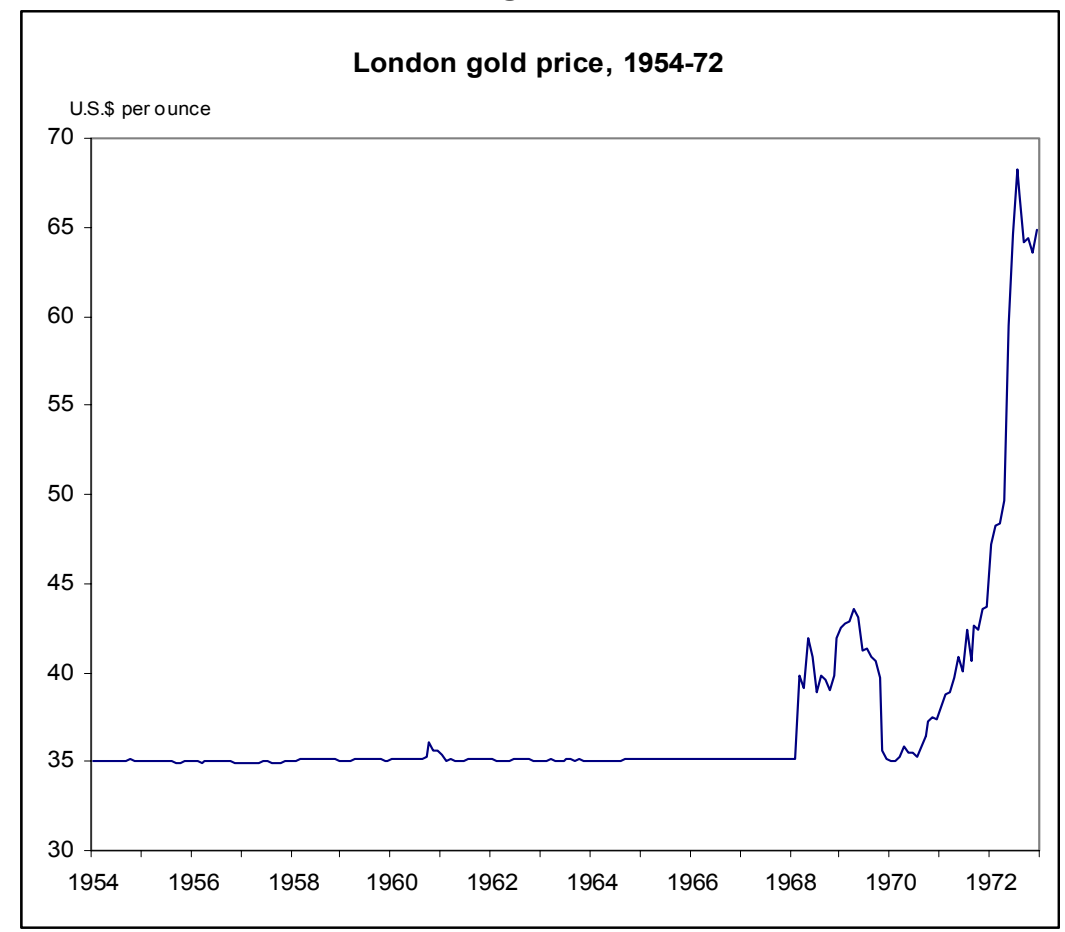

Source: IMF, International Financial Statistics 


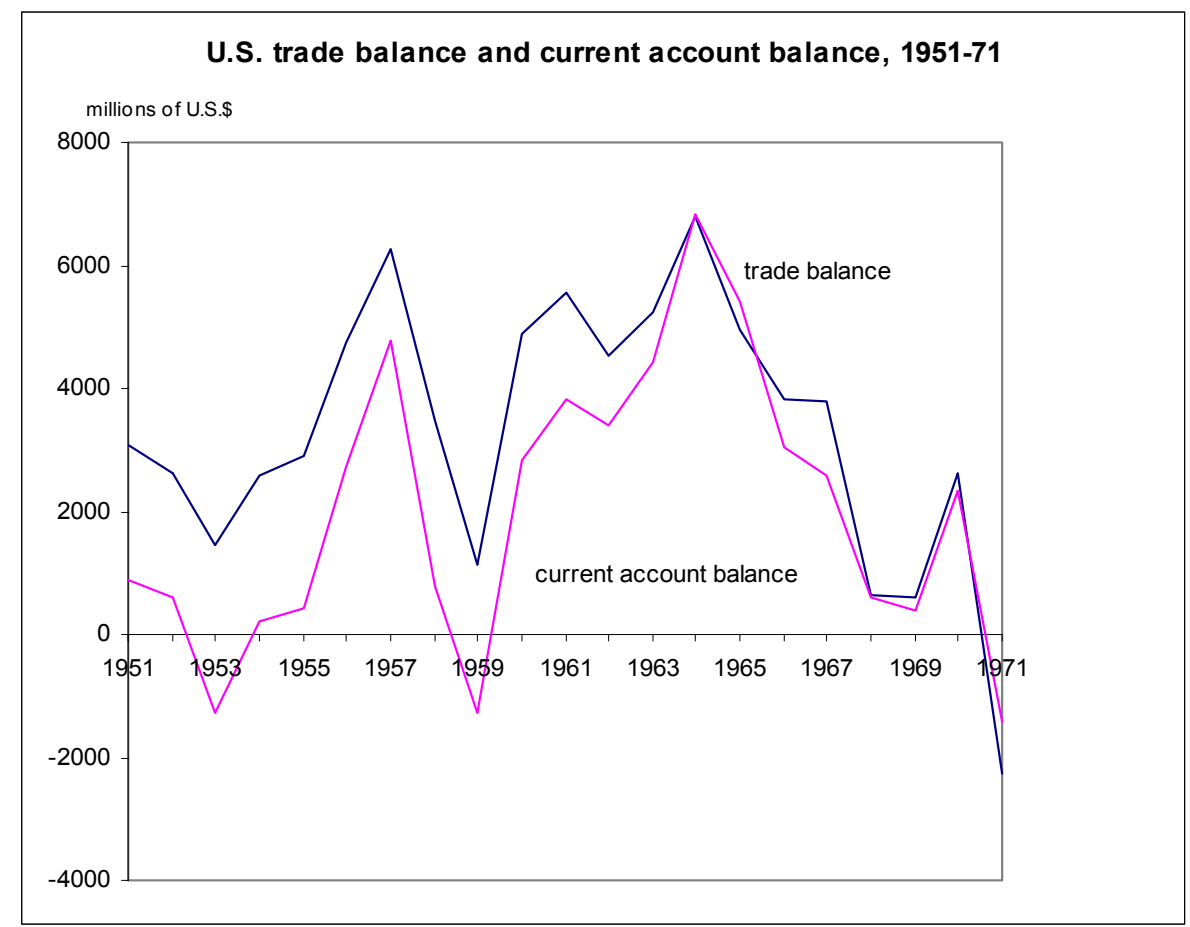

Source: Economic Report of the President, Transmitted to the Congress, 1984. 
Figure 5

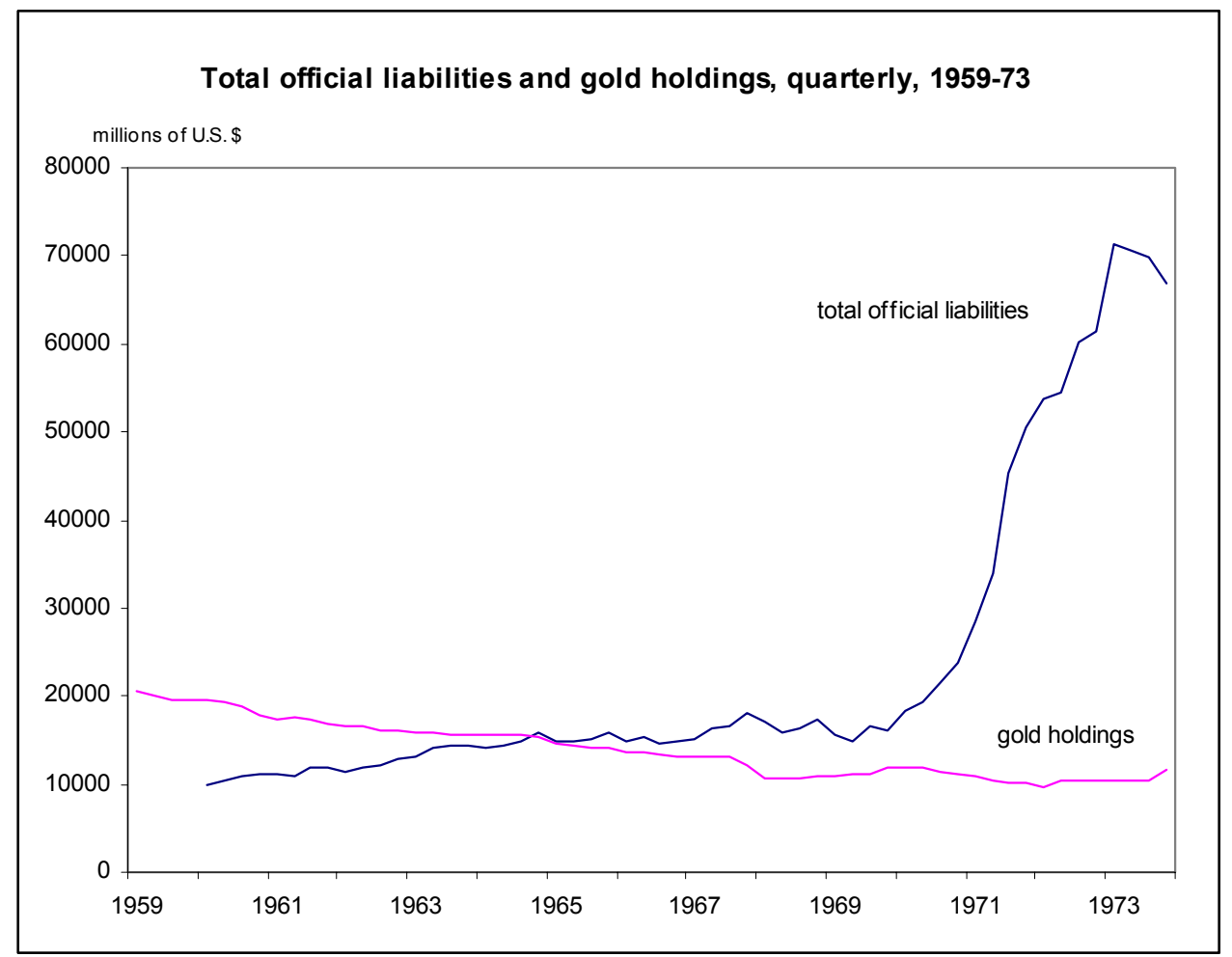

Source: IMF, International Financial Statistics 
Figure 6

Official reserve composition by country foreign exchange reserves, gold reserves, and total reserves for each member of the Gold Pool
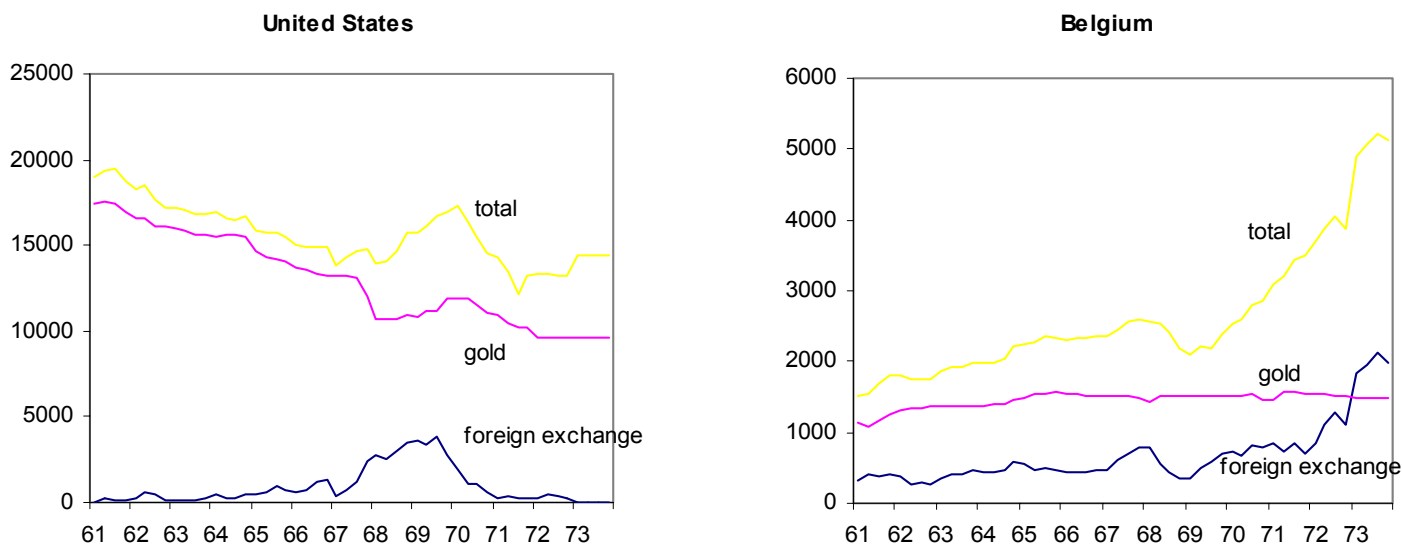

France

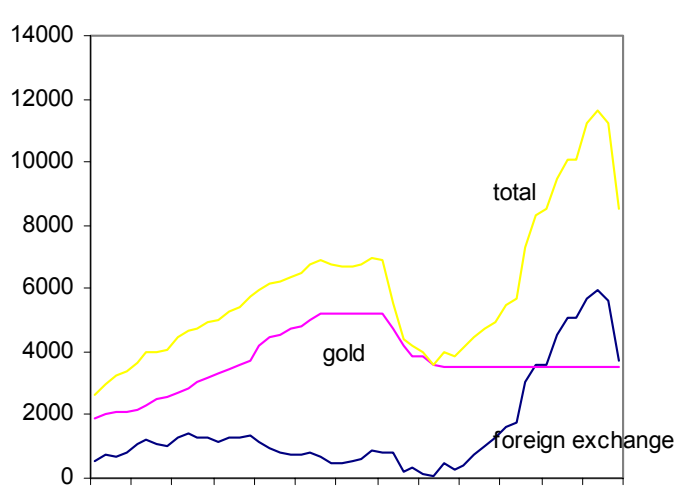

$\begin{array}{lllllllllllll}61 & 62 & 63 & 64 & 65 & 66 & 67 & 68 & 69 & 70 & 71 & 72 & 73\end{array}$
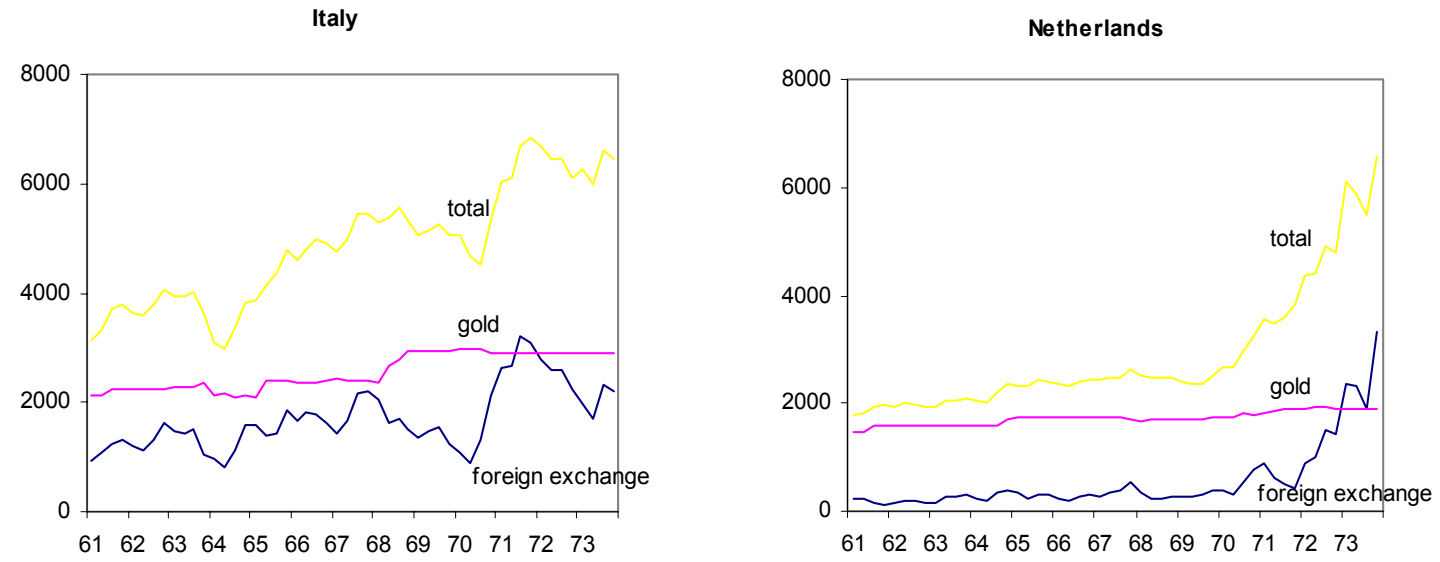

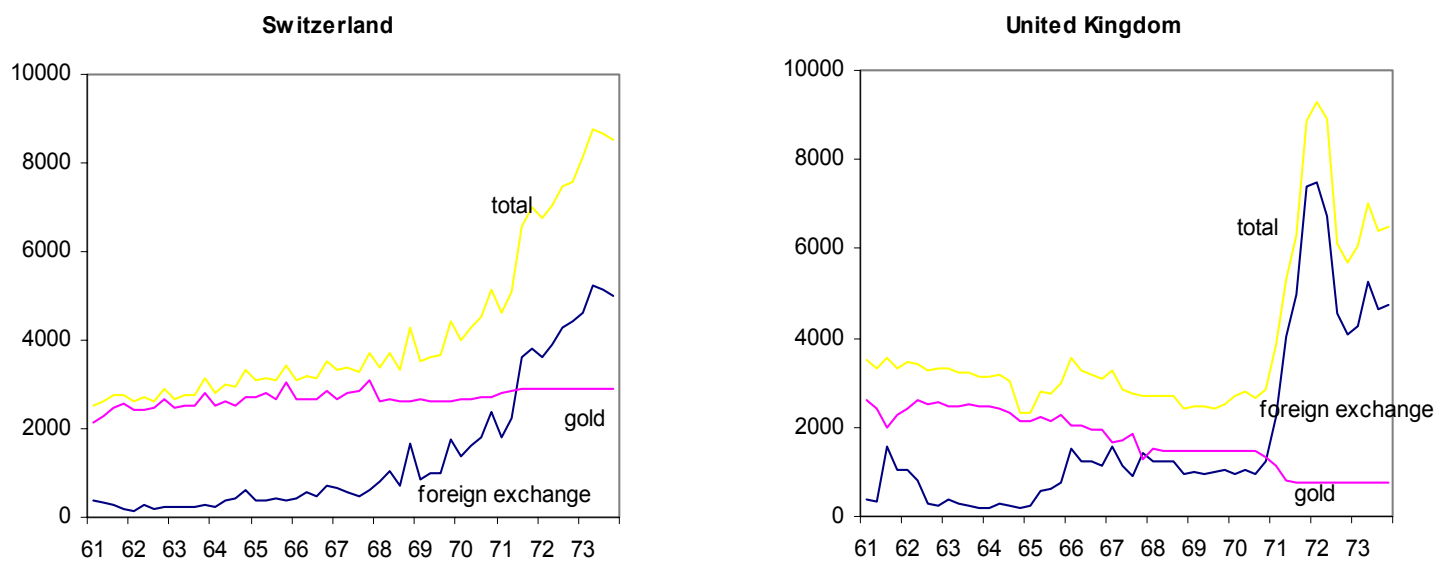

Source: IMF, International Financial Statistics 